\title{
Puncture of the Axillary Vein for the Implant for Electronic Cardiac Devices
}

\author{
Punção da Veia Axilar para o Implante de Dispositivos Cardíacos Eletrônicos
}

Vagner Rossato Pegoraro ${ }^{1, *}$, Eduardo Rodrigues Bento Costa ${ }^{1}$, Luiz Fernando Fagundes Gouvea Filho', Beatriz Tose Costa Paiva ${ }^{2}$

\author{
ORCID IDS \\ Pegoraro VR (D) https://orcid.org/0000-0003-3448-320X \\ Costa ERB (iD https://orcid.org/0000-0002-3342-5369 \\ Gouvea Filho LFF (D) https://orcid.org/0000-0002-5199-1233 \\ Paiva BTC (D) https://orcid.org/0000-0002-2516-1770
}

\begin{abstract}
Introduction: The obtaining of venous access for implantation of implantable electronic cardiac devices (IECDs) has been traditionally made by intrathoracic subclavian vein puncture (SVP) or cephalic vein phlebotomy (CVP). Evidence indicates, however, the increased risk of short-term and long-term complications with SVP due to the fact that it is intrathoracic access and the risk of compression of the electrodes by the costoclavicular ligament, leading to different types of defects. CVP, in turn, has been associated with a failure rate that reaches $45 \%$. Axillary vein puncture (AVP) has been described in the literature and is presented here as an alternative to the two techniques mentioned. Methods: A PubMed survey was conducted on articles that mention the AVP, SVP and CVP techniques and compare them to the immediate, short and long term results and success rates for obtaining venous access. Emphasis was placed on comparisons between the various AVP techniques. Conclusion: The AVP technique for obtaining venous access presents some variations among the different authors. It has CVP-like safety, success rates comparable to those of the subclavian vein, and better medium and long term results for electrode function.
\end{abstract}

KEYWORDS: Axillary vein puncture; Cephalic vein phlebotomy; Subclavian vein puncture; Complications with pacemaker implantation.

\section{RESUMO}

Introdução: A obtenção do acesso venoso para implante de dispositivos cardíacos eletrônicos implantáveis (DCEIs) tem sido tradicionalmente feita por meio da punção da veia subclávia intratorácica (PVS) ou por flebotomia da veia cefálica (FVC). Evidências apontam, entretanto, para o risco aumentado de complicações a curto e longo prazos com a PVS pelo fato de ser um acesso intratorácico e pelo risco de compressão dos eletrodos pelo ligamento costoclavicular, levando a diferentes tipos de defeitos. A FVC, por sua vez, tem sido associada à taxa de insucesso que chega a 45\%. A punção da veia axilar (PVA) tem sido descrita na literatura e é apresentada, aqui, como alternativa às duas técnicas mencionadas. Métodos: Realizou-se uma pesquisa pelo PubMed sobre artigos que mencionam as técnicas de PVA, PVS e FVC e que as comparam quanto aos resultados imediatos, a curto e longo prazos e taxas de sucesso para a obtenção do acesso venoso. Deu-se ênfase às comparações entre as diversas técnicas de PVA. Conclusão: A técnica de PVA para obtenção do acesso venoso apresenta algumas variações entre os diversos autores. Ela tem segurança semelhante à da FVC, taxas de sucesso comparáveis às da veia subclávia e melhores resultados a médio e a longo prazos para a função dos eletrodos.

PALAVRAS-CHAVE: Punção da veia axilar; Flebotomia da veia cefálica; Punção da veia subclávia; Complicações com implante de marcapassos.

1.CardioRitmo - Clínica de Arritmias Cardíacas - São José dos Campos/SP - Brazil.

2.REGIOMED Klinikum - Coburg - Germany.

*Correspondence author: vagnerpeg@yahoo.com.br

Received: 18 Feb 2018 | Accepted: 09 Jul 2018

Section Editor: J. Tarcisio Medeiros de Vasconcelos 


\section{INTRODUCTION}

Obtaining venous access for implantation of implantable cardiac devices (ICDs) is an essential part of the procedure. The choice of puncture technique should take into account factors such as the chance of success, the risks of immediate and future complications and the time required to obtain them. Several techniques have been described, all with their particularities and limitations. The intrathoracic subclavian vein puncture (SVP) technique was introduced by Littleford et al. ${ }^{1}$, in 1979 . It was widely accepted because it is fast, easy to learn, and has high success rates. Thus, it has been the most widely used electrode implant method in the world ${ }^{2-4}$. In Brazil, this is also the most used venous access, followed by cephalic vein phlebotomy (CVP). Subclavian access, however, is associated with a greater risk of both immediate complications - pneumothorax, hemothorax, arterial puncture, brachial plexus injury and late - insulation defects, electrode fractures, capture losses, abnormal impedances and sensing failures ${ }^{5,6}$. CVP, although quite safe, has been less and less used due to the failure rate that varies from 15 to $45 \%{ }^{7}$.In this work, we will review the axillary vein puncture technique (AVP), presenting the similarities and variations between the different authors, as well as their respective success rates, and compare it with the other techniques.

\section{METHODS}

A PubMed survey was conducted on articles that mention AVP techniques. Those who described the AVP techniques or those who compared them to those of SVP or CVP were selected for immediate, short- and long-term results, and success rates for obtaining venous accesses. The survey covers articles published between 1979 and 2017. Emphasis was placed on comparisons between the various AVP techniques.

\section{AVP}

The axillary vein originates from the junction of the cephalic and basilic veins. It extends to the lower margin of the first rib where it continues as the subclavian vein ending with its junction with the internal jugular ${ }^{8}$.
AVP can be performed using contrast venography, contrast-free fluoroscopy, ultrasonography, or even anatomical landmarks only.

For fluoroscopy-guided AVP, data from venography studies that evaluate the usual path of the axillary vein are used. One demonstrated that the axillary vein runs parallel to the deltopectoral sulcus (DPS) between one finger $(1.85 \mathrm{~cm})$ and one finger and a half $(2.8 \mathrm{~cm})$ more medially and follows its course towards the most prominent point of the clavicle (MPPC) .

This MPPC approximately corresponds to the crossing of the clavicle with the lateral margin of the first rib ${ }^{10,11}$. The axillary vein in its course parallel to the DPS also passes over the anterior body of the second rib, at the point where it crosses over the posterior shadow of the third rib (lateral radiological limit of the rib cage). Thus, with fluoroscopy, the needle can be directed to one of these two points from the pacemaker pocket (Fig. 1).

To reach these points, several authors have used varied techniques that can be generally grouped into two methods. In the first one, it begins by making the incision to the IECD pocket below $(1.5-2 \mathrm{~cm})$ and parallels to the clavicle, with this extending to the DPS. Then, the puncture needle is coupled to a syringe and puncture is performed from the IECD pocket. The tip of the needle is placed from the IECD pocket under fluoroscopy on the first rib, with an initial angle of approximately $60^{\circ}$ (steep angle) in relation to the body surface (BS). The needle is then advanced and if it passes from the rib margin it is partially withdrawn and reintroduced with a greater angle (which can reach $90^{\circ}$ ) so that it is always seen on the first rib while it is advanced. From the moment it touches the rib, aspiration begins at the same time the needle is slowly drawn back. If blood cannot be aspirated, the process is repeated a little more laterally or medially, always with the needle on the radiological image of the first rib. The same technique can be used with the needle directed to a second target: the second rib body at the point where it intersects with the posterior shade of the third rib - which leads to more lateral puncture of the vein. Care should be taken that the needle always points to the anterior arch of the target rib since the inadvertent choice of a posterior arch may cause the needle to cross the intercostal muscles and the puncture result in a pneumothorax $^{12,13}$. 
In the second method, the incision can be made on the DPS or slightly medial to it (in the second case, it is approximately on the usual path of the axillary vein). The needle is inserted under fluoroscopy from the pacemaker's pocket at a lower angle (shallow angle) to the skin $\left(10-30^{\circ}\right)$, targeting the same crossing point of the clavicle with the lateral face of the first rib. This puncture angle allows greater needle reaches to puncture the axillary vein from the DPS (Fig. 2). This method of puncture was first described by Byrd $^{10}$ and subsequently used by others ${ }^{14}$.

Magney ${ }^{15}$ was the first to use anatomical landmarks for AVP, which was done transcutaneously. Gardini and Benedini ${ }^{16}$, using the same anatomical references, began to perform the puncture from the inside of the IECD pocket, both described in Table 1 . The techniques that came after the axillary vein were targeted in their passage through the crossing of the lateral margin of the first rib with the clavicle (CC1C) or more lateral portions of this, in the latter case, on the crossing of the anterior aspect of the second rib with the posterior shadow of the third. For this purpose, the DPS (or cephalic vein) can be used as the anatomical landmarks as the point of origin and the MPPC as the target point. The latter, being palpable, serves as a target to guide the direction of the needle. With the knowledge that the axillary vein passes $1.8-2.8 \mathrm{~cm}$ medially to the DPS, the needle - aligned with the vein path - is directed to the place where the
MPPC is palpated ${ }^{9,17}$. In this case, the puncture should be made on the superficial pectoral muscles with a small angle (up to $30^{\circ}$ ) in relation to BS. If success were not achieved, it would be possible to use fluoroscopy with contrast venography from cannulation of the cephalic vein (if it was dissected to be used as a reference) or from a peripheral vein to identify any anomalous path ${ }^{17}$.

Pittiruti et al. ${ }^{18}$, in axillary vein Doppler studies, have shown that abduction of the arm, especially if associated with a certain shoulder elevation (with compresses behind the shoulder, for example), increased the diameter of the axillary vein and may facilitate its blind puncture ${ }^{18}$.

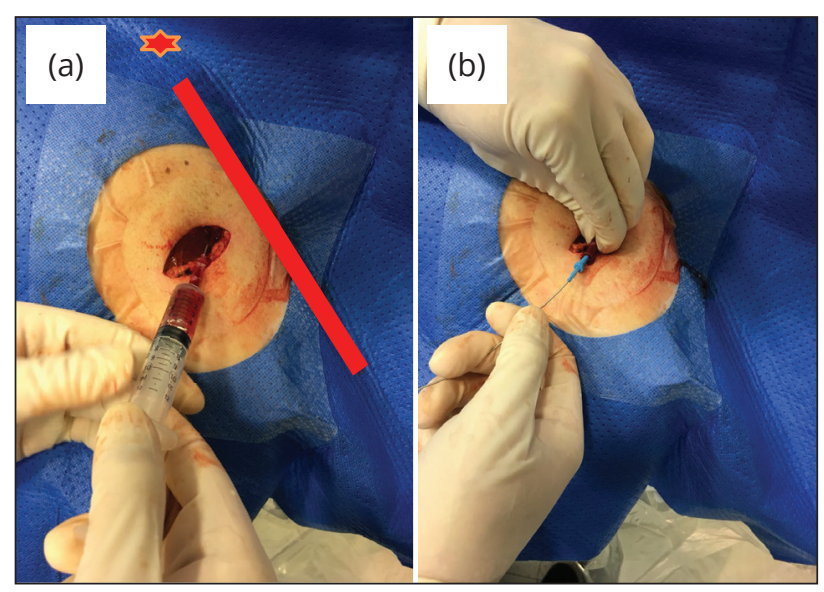

Figure 2. (a) Axillary puncture made from the pacemaker pocket located on the deltopectoral sulcus with an angle of approximately 15-20 degrees to the body surface. Red line indicates the clavicle position. The red star indicates the jugular notch of the manubrium. (b) Guidewire introduction. (a)

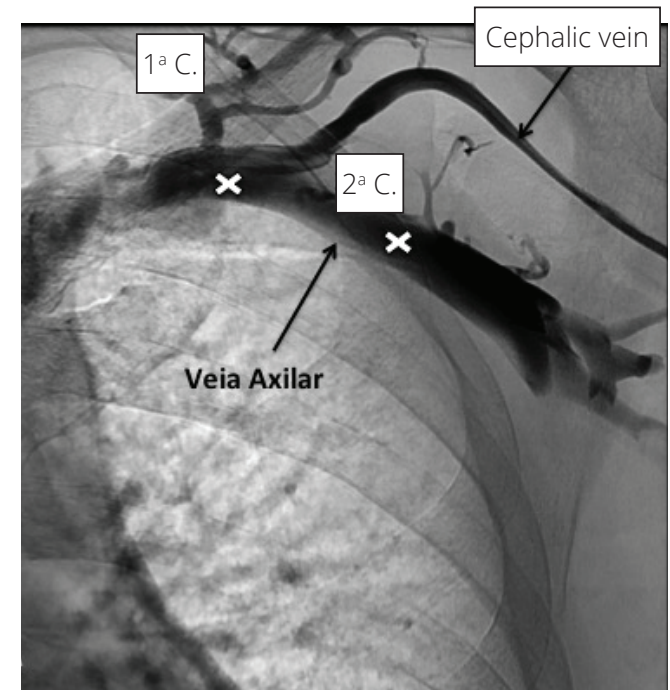

(b)

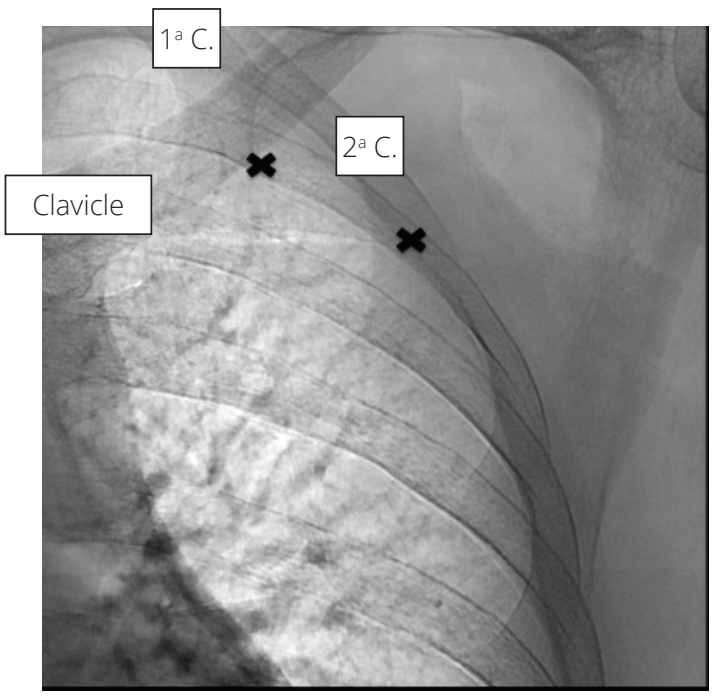

Figure 1. Radiological references for axillary puncture. (a) Radioscopic image of venography performed from peripheral venous access showing the cephalic and axillary veins, first and second ribs and puncture reference points (marked with $\times$ ). (b) Radioscopic image showing the same points of puncture using two points as reference: the first as the crossing of the clavicle with the lateral margin of the first rib ( $\times$ above and medial) and the second the surface of the second rib when it crosses with the posterior shadow of the third ( $x$ below and lateral). 
Table 1. Comparisons between axillary vein puncture techniques.

\begin{tabular}{|c|c|c|c|c|}
\hline References & Incision for the IECD pocket & $\mathrm{XR}$ & Puncture site/target /angle & Sucess rate \\
\hline Magney et al. ${ }^{15}$ & Not described & No & $\begin{array}{l}\text { Entry (percutaneous puncture): junction of the } \\
\text { 1/3 middle and 1/3 lateral of a line between PC } \\
\text { and MEA midpoint. } \\
\text { Target: } 1 / 3 \text { medial junction with 1/3 medial } \\
\text { clavicle. }\end{array}$ & Not described \\
\hline Ramza et al. ${ }^{25}$ & $\begin{array}{l}\text { Parallel to the clavicle } \\
(2 \mathrm{~cm} \text { below })\end{array}$ & $\begin{array}{l}\text { Yes } \\
X R+C\end{array}$ & $\begin{array}{l}\text { Target: 1) Axillary vein in more medial or "in" } \\
\text { portion of the rib cage; } 2 \text { ) Axillary vein in more } \\
\text { lateral or "out" portion of the rib cage.* } \\
\text { Angle: } 60^{\circ} \text { with SC. Parallel to the vein. }\end{array}$ & $\begin{array}{l}\text { Medial: } 100 \% \\
\text { Lateral: } 83 \%{ }^{+}\end{array}$ \\
\hline Gardini et al. ${ }^{16}$ & $\begin{array}{l}\text { Parallel to the clavicle } \\
(2 \mathrm{~cm} \text { below })\end{array}$ & No & $\begin{array}{l}\text { Modified Magney's technique, same references, } \\
\text { but with the puncture from the inside of the } \\
\text { pocket and not percutaneous. }\end{array}$ & $98 \%$ \\
\hline Belott ${ }^{12}$ & $\begin{array}{l}\text { Starts slightly below the } \\
\text { coracoid process and runs } \\
\text { perpendicular to the DPS }\end{array}$ & Yes & $\begin{array}{l}\text { Target: 1) First rib at the intersection with the } \\
\text { clavicle; } 2 \text { ) Second rib on the lateral margin of } \\
\text { the rib cage (where the anterior radiological } \\
\text { remnant of the second rib crosses the posterior } \\
\text { radiological shadow of the third rib). } \\
\text { Angle: } 60-90^{\circ} \text { (steep). }\end{array}$ & $98,21 \%$ \\
\hline Sharma et al. ${ }^{20}$ & On the DPS & Yes & $\begin{array}{l}\text { Entry: crossing point of the second rib, with } \\
\text { radiological lateral margin of the rib cage. } \\
\text { Angle: } 60^{\circ} \\
\text { Target: Crossing of the clavicle with the lateral } \\
\text { edge of the first rib. }\end{array}$ & $98,09 \%$ \\
\hline Antonelli et al. ${ }^{11}$ & $\begin{array}{l}\text { Parallel to DPS } \\
(1 \mathrm{~cm} \text { medial to it) and } 2 \mathrm{~cm} \\
\text { below the collarbone }\end{array}$ & Yes & $\begin{array}{l}\text { Entry: upper incision edge. } \\
\text { Target: 1st rib crossing with the clavicle. } \\
\text { Angle: tangential to the thoracic surface. }\end{array}$ & $94,5 \%$ \\
\hline Jiang et al. ${ }^{14}$ & Parallel to clavicle & Noł & $\begin{array}{l}\text { Entry and angles: Steep needle technique - the } \\
\text { angle of } 60^{\circ} \text { in relation to BS. From point } 2 \mathrm{~cm} \\
\text { medial to DPS. } \\
\text { Shallow needle technique: From the lateral } \\
\text { portion (closest to SCP) of the incision with a } 10^{\circ} \\
\text { angle to the BS. } \\
\text { Target: } 1 / 3 \text { to } 1 / 4 \text { plus a medial portion of the } \\
\text { clavicle. }\end{array}$ & $\begin{array}{c}\text { Blind/XR } \\
\text { Steep: } 51 / 54 \% \\
\text { Shallow: } 89 / 94 \%\end{array}$ \\
\hline Mehrotra et al. ${ }^{9}$ & $\begin{array}{l}\text { Parallel to the DPS, } 1 \text { finger } \\
\text { and a half medial to it. Top } \\
\text { of the incision lies } 2 \text { fingers } \\
\text { below the collarbone }\end{array}$ & No & $\begin{array}{l}\text { Entry: with the needle in the direction of the } \\
\text { incision (one finger and medial half to the DPS). } \\
\text { Target: MPPC } \\
\text { Angle: } 60^{\circ} \text { in relation to BS }\end{array}$ & $95 \%$ \\
\hline Migliori et al. ${ }^{13}$ & $\begin{array}{l}\text { Parallel to the clavicle }(2 \mathrm{~cm} \\
\text { below), extending up to } 1 \mathrm{~cm} \\
\text { medial to DPS }\end{array}$ & Yes & $\begin{array}{l}\text { Target: 1) Crossing the clavicle with the lateral } \\
\text { edge of the first rib; 2) Body surface of the } \\
\text { second rib (at the point where the anterior } \\
\text { shadow of the second rib crosses the posterior } \\
\text { shadow of the third) } \\
\text { Angle: } 60^{\circ} \text {. }\end{array}$ & $93,2 \%$ \\
\hline Imnadze et al. ${ }^{17}$ & $\begin{array}{l}\text { Parallel to the clavicle } \\
(2-3 \mathrm{~cm} \text { below) going to the } \\
\text { DPS, where the cephalic vein } \\
\text { was dissected }\end{array}$ & & $\begin{array}{l}\text { Entry: } 1.5-2 \mathrm{~cm} \text { medial to the cephalic vein, } \\
\text { leaving the needle parallel to it. } \\
\text { Target: axillary vein in the most distal portion. } \\
\text { Angle: } 30^{\circ} \text { in relation to BS, with a needle parallel } \\
\text { to the cephalic vein. }\end{array}$ & $92,6 \%$ \\
\hline Squara et al. ${ }^{19}$ & Parallel to clavicle & Yes & Same Bellot technique. & $81 \%$ \\
\hline
\end{tabular}

Target: vein point to be punctured [when more than one possible target point can be used (one or the other), have been set to 1 or 2]; MSA: manubrium-sternal angle; IECD: implantable electronic cardiac device; entry: entry point of the punch needle to then be directed to the target; PC: coracoid process; MPPC: most prominent point of the clavicle; RX: radioscopy/fluoroscopy; RX + C: contrast radioscopy; BS: body surface; DPS: deltopectoral sulcus; shallow: angle punch of approximately $10^{\circ}$-30; steep: angle punch between $60^{\circ}$ and $90^{\circ}$ **: Ramza used contrast venography and divided the axillary vein into medial and lateral. The medial portion corresponded to the vein "inside" the rib cage bone; the lateral portion to the axillary vein outside the limits of the rib cage. $t$ : in all patients from Ramza who did not succeed with a more lateral puncture, success was obtained when the most medial puncture was subsequently used. ¥: jiang et al. initially tested for AP blindly, followed by fluoroscopy if it did not work. 


\section{DISCUSSION}

Obtaining venous access by the intrathoracic subclavian can be justified by the premise that the best way to do a procedure is to do the way one has the most experience. In fact, this has been the most used technique in Brazil and worldwide ${ }^{2-4}$. Several data, however, have shown that other forms of venous access with punctures that access the vascular bed in an extrathoracic location, such as AVP, may be equal or easier, safer, and present a lower risk of short- and long-term complications ${ }^{19-24}$.

Because the subclavian vein is a vessel with intrathoracic stroke, its puncture has been more associated with acute complications, especially the occurrence of pneumothorax (1.9-3.06\%) when compared to AVP $14,20,25$ (Table 2). An example was a population cohort of 28,860 patients (Danish cohort) with IECD implantation evaluated for the occurrence of pneumothorax requiring drainage. The greatest predictor of its occurrence was obtaining access by SVP [odds ratio (OR) $=7.8 ; 95 \%$ confidence interval (95\% CI) 4.9-12.5 $]^{26}$. The most frequent complication associated with AVP was the occurrence of an arterial puncture in the attempt to obtain venous access. CVP is practically not associated with acute complications, except for the possible occurrence of hematoma at the pocket location.

The techniques described for AVP aim to use reference points that facilitate puncture without the risk of complications. If it is possible to perform it without the use of contrast, complications can be avoided such as spasm of the vein, nephropathy in patients with already depressed renal function, anaphylaxis or the need for adequate venipuncture ipsilateral to the puncture site. High success rates have been described for AVP using as reference fluoroscopic or only anatomical landmarks ${ }^{8,11,13,16,19,20}$, reserving the use of contrast for failure cases. When compared to the SVP technique, AVP has demonstrated similar success rates for vein cannulation $^{19,20}$. AVP was even associated with a higher success rate in the first puncture attempt than SVP (61 vs. $36.8 \%),{ }^{20}$. Although having a lower success rate, CVP has always been associated with greater safety, both because it is an extrathoracic technique and because it does not cause inadvertent risk of arterial puncture or brachial plexus injury. To test the safety of AVP, Squara et al. ${ }^{19}$ evaluated the AVP without the venography, comparing it with the CVP in a center where no electrophysiologist received any training or had any experience with the AVP. They only received material with a detailed description of the Belott technique before attempting to use the technique for the first time. With similar safety results - among them no pneumothorax - and high success rate, it has been shown that the lack of experience should not be impeding the adoption of AVP as a technique of choice ${ }^{19}$. A Brazilian study also confirmed its safety and efficacy ${ }^{27}$.

The techniques for AVP aim to use anatomical or radiological references for points on which the axillary vein passes more frequently, to facilitate the obtaining of the venous access. For this purpose, the various authors described their techniques with variations in relation to the pocket location, needle entry site, the target site for axillary vein puncture and needle angle for puncture. The latter can be large (60-90 - steep) or small, to the point of torsening the rib cage $\left(10-30^{\circ}\right.$ - shallow) (Table 1$)$. In general, when the pockets were made parallel to the clavicle, larger angles were used between the needle and $\mathrm{SC}$, because there was greater proximity to the crossing of the first rib and clavicle (CC1C). In contrast, pockets parallel to DPS were associated with smaller angles for puncture when the target was $\mathrm{CC} 1 \mathrm{C}$ - larger when the axillary vein was positioned more lateral (near the lateral radiological margin of the rib cage).

Ultrasonography can be used to guide the AVP. It certainly offers advantages such as direct visualization of the vessel and its anatomical relationships ${ }^{28}$, but it has the disadvantage that it is necessary to have this equipment in the room and also to extend the procedure.

When the possible consequences of the different types of access to the vascular bed on the durability of the electrodes were evaluated, important differences were observed.

Kim et al. ${ }^{22}$ compared the SVP technique with that of AVP in the insertion of 1,161 pacemaker electrodes. There was a $53 \%$ reduction in the risk of complications electrode fracture or defects in insulation - with axillary access compared to subclavian. Chan et al. ${ }^{23}$ followed the occurrence of failures in 681 implanted electrodes for an average period of $73.6( \pm 33.1)$ months and the occurrence of defects was identified as $2.9 \%$. AVP was an independent predictor for lower risk of electrode failure compared to SVP [hazard ratio $(\mathrm{HR})=0.26 ; 95 \% \mathrm{CI}$ 0.071-0.954).Jacobs 
Table 2. Comparison between techniques for obtaining vascular access.

\begin{tabular}{|c|c|c|c|c|c|c|c|c|}
\hline References & $\begin{array}{l}\text { Patients } \\
\text { (n) }\end{array}$ & $\begin{array}{l}\text { Pneumothorax } \\
\text { (\%) }\end{array}$ & $\begin{array}{c}\text { Hemothorax } \\
\text { (\%) }\end{array}$ & $\begin{array}{c}\text { Arterial } \\
\text { puncture } \\
(\%)\end{array}$ & $\begin{array}{l}\text { Pocket } \\
\text { bruise } \\
(\%)\end{array}$ & $\begin{array}{c}\text { Brachial } \\
\text { plexus injury } \\
(\%)\end{array}$ & $\begin{array}{c}\text { Limb } \\
\text { thrombosis } \\
(\%)\end{array}$ & $\begin{array}{c}\text { Success } \\
(\%)\end{array}$ \\
\hline \multicolumn{9}{|l|}{ Axillary vein } \\
\hline Sharma20 & 202 & 0.00 & 0.00 & ND & 4.40 & ND & ND & 98.00 \\
\hline Antonelli11 & 182 & 0.00 & 0.00 & 3.30 & 0.00 & 0.00 & ND & 100.00 \\
\hline Imnadze ${ }^{17}$ & 108 & 0.00 & 0.00 & 4.60 & ND & 0.00 & ND & 92.60 \\
\hline Jiang shallow ${ }^{14^{*}}$ & 460 & 0.00 & ND & 7.50 & 0.50 & 0.00 & ND & 94.00 \\
\hline Jiang steep $\mathrm{p}^{14^{*}}$ & 140 & 0.00 & 0.00 & 7.90 & 0.00 & 1.30 & ND & 54.00 \\
\hline Migliori13 & 103 & 0.00 & 0.00 & 2.00 & ND & $N D$ & ND & 100.00 \\
\hline Byrd $^{10}$ & 213 & 0.00 & 0.00 & $N D$ & ND & ND & ND & 98.00 \\
\hline Saad $^{27}$ & 241 & 0.00 & 0.00 & 5.00 & ND & ND & 0.40 & 100.00 \\
\hline Mehrotra9 & 20 & 5.00 & ND & $N D$ & ND & ND & $N D$ & 95.00 \\
\hline Ramza $^{25}$ & 50 & 0.00 & 0.00 & 8.10 & ND & ND & ND & 98.00 \\
\hline Squara ${ }^{19}$ & 37 & 0.00 & 0.00 & ND & 2.70 & 5.40 & ND & 81.00 \\
\hline \multicolumn{9}{|l|}{ Subclavian vein } \\
\hline Sharma ${ }^{20}$ & 98 & 3.06 & ND & ND & 4.00 & ND & ND & 96.90 \\
\hline Aggarwal29 & 1.047 & 1.80 & ND & 2.70 & ND & ND & ND & ND \\
\hline Chauhan ${ }^{30}$ & 1.892 & $0.6 \dagger$ & ND & $N D$ & 0.50 & ND & ND & ND \\
\hline Litleford $^{1}$ & 164 & 2.40 & ND & ND & 1.20 & ND & ND & 91.70 \\
\hline Marinoni ${ }^{31}$ & 1.220 & 0.30 & ND & ND & $N D$ & ND & ND & ND \\
\hline Kirkfeldt ${ }^{26}$ & 12.260 & $0.66+$ & ND & ND & ND & ND & ND & ND \\
\hline Eberhardt ${ }^{32}$ & 1.100 & $1.1 \neq$ & ND & ND & ND & ND & ND & ND \\
\hline Fiorista ${ }^{33}$ & 101 & 3.00 & ND & ND & ND & 4.30 & ND & ND \\
\hline Hess $^{34}$ & 171 & 0.00 & 0.00 & ND & ND & 0.00 & ND & ND \\
\hline \multicolumn{9}{|l|}{ Cephalic vein } \\
\hline Chauhan 30 & 157 & 0.00 & 0.00 & ND & 2.60 & ND & ND & ND \\
\hline Squara ${ }^{19}$ & 37 & 0.00 & 0.00 & ND & 5.40 & 0.00 & 0.00 & 75.70 \\
\hline Kircanskij5 & 44 & 0.00 & 0.00 & 0.00 & 0.00 & 0.00 & 0.00 & 90.10 \\
\hline Parsonnet ${ }^{36}$ & 148 & 0.67 & ND & ND & $N D$ & $N D$ & $N D$ & ND \\
\hline
\end{tabular}

ND: not described, unspecified or without separation of values between groups compared; *: Jiang shallow and steep are part of the same work but represent different axillary vein access techniques. t: authors who defined as the occurrence of pneumothorax only the cases requiring drainage. Cases without drainage are not included; $¥$ : cases of pneumothorax requiring drainage in which the implanted pacemaker was a double chamber.

et al. ${ }^{24}$ made an even more detailed evaluation of defective electrodes extracted with the use of electrical tests, light microscopy, electron microscopy, and tests to evaluate the pressure on the electrodes. The analysis of the electrodes by specialists showed that the occurrence of pressure in the costoclavicular transition was responsible for the greater incidence of defects when the venous access was subclavian and suggested a more lateral approach, such as the use of the axillary vein, as a preventive for these complications.

\section{CONCLUSIONS}

The AVP technique has been described by several authors and presents some variations. It is a valuable alternative for obtaining venous access, presenting similar safety to CVP (even in the learning phase), success rates comparable to those of the subclavian vein and better medium and long term results for the function of the electrodes.

\section{AUTHORS' CONTRIBUTION}

Methodology, Pegoraro VR, Costa ERB and Gouvea Filho LFF; Investigation, Pegoraro VR, Paiva BTC and Gouvea Filho LFF; Writing first version, Pegoraro VR and Paiva BTC; Writing - Review \& Editing, Pegoraro VR and Costa ERB; Supervision,Costa ERB.

\section{ACKNOWLEDGMENTS}

To Dr. Eduardo R. B. Costa for guiding us in this work. 


\section{REFERENCES}

1. Littleford PO, Parsonnet $V$, Spector SD. Method for the rapid and atraumatic insertion of permanent endocardial pacemaker electrodes through the subclavian vein. Am J Cardiol. 1979;43(5):980-2. https://doi.org/10.1016/00029149(79)90363-1

2. Bernstein $A D$, Parsonnet $V$. Survey of cardiac pacing in the United States in 1989. Am J Cardiol. 1992;69(4):331-8. https://doi.org/10.1016/0002-9149(92)90229-R

3. Bernstein $A D$, Parsonnet $V$. Survey of cardiac pacing and defibrillation in the United States in 1993. Am J Cardiol. 1996;78(2):187-96.

4. Mond HG, Proclemer A. The 11th world survey of cardiac pacing and implantable cardioverter-defibrillators: calendar year 2009 - A World Society of Arrhythmias project. Pacing Clin Electrophysiol. 2011;34(8):1013-27. https://doi. org/10.1111/j.1540-8159.2011.03150.x.

5. Kleemann $T$, Becker $T$, Doenges $K$, Vater $M$, Senges J, Schneider S, et al. Annual rate of transvenous defibrillation lead defects in implantable cardioverter-defibrillators over a period of $>10$ years. Circulation. 2007;115(19):2474-80. https://doi.org/10.1161/CIRCULATIONAHA.106.663807

6. Dorwarth U, Frey B, Dugas M, Matis T, Fiek M, Schmoeckel $M$, et al. Transvenous defibrillation leads: high incidence of failure during long-term follow-up. J Cardiovasc Electrophysiol. 2003;14(1):38-43. https://doi.org/10.1046/ j.1540-8167.2003.02305.x

7. Calkins H, Ramza BM, Brinker J, Atiga W, Donahue K, Nsah E, et al. Prospective randomized comparison of the safety and effectiveness of placement of endocardial pacemaker and defibrillator leads using the extrathoracic subclavian vein guided by contrast venography versus the cephalic approach. Pacing Clin Electrophysiol. 2001;24(4 Pt 1):456-64.

8. Jiang M, Mao JL, He B. Clinical definition of the axillary vein and experience with blind axillary puncture. Int J Cardiol. 2012;159(3):243-5. h. https://doi.org/10.1016/j. ijcard.2012.05.089

9. Mehrotra S, Rohit MK. Prospective study to develop surface landmarks for blind axillary vein puncture for permanent pacemaker and defibrillator lead implantation and compare it to available contrast venography guided technique. Indian Heart J. 2015;67(2):136-40. https://doi.org/10.1016/j. ihj.2015.04.007

10. Byrd CL. Clinical experience with the extrathoracic introducer insertion technique. Pacing Clin Electrophysiol. 1993;16(9):1781-4. https://doi.org/10.1111/j.1540-8159.1993. tb01810.x

11. Antonelli D, Feldman A, Freedberg NA, Turgeman $Y$. Axillary vein puncture without contrast venography for pacemaker and defibrillator leads implantation. Pacing Clin Electrophysiol. 2013;36(9):1107-10. https://doi.org/10.1111/ pace.12181

12. Belott P. How to access the axillary vein. Heart Rhythm. 2006;3(3):366-9. https://doi.org/10.1016/j.hrthm.2005.10.031

13. Migliore F, Siciliano M, De Lazzari M, Ferretto S, Valle CD, Zorzi A, et al. Axillary vein puncture using fluoroscopic landmarks: a safe and effective approach for implantable cardioverter defibrillator leads. J Interv Card Electrophysiol. 2015;43(3):2637. https://doi.org/10.1007/s10840-015-0011-7

14. Jiang M, Gong XR, Zhou SH, Pu J, Mao JL, He B. A comparison of steep and shallow needle trajectories in blind axillary vein puncture. Pacing Clin Electrophysiol. 2013;36(9):1150-5. https://doi.org/10.1111/pace.1215

15. Magney JE, Staplin DH, Flynn DM, Hunter DW. A new approach to percutaneous subclavian venipuncture to avoid lead fracture or central venous catheter occlusion. Pacing Clin Electrophysiol. 1993;16(11):2133-42. https://doi. org/10.1111/j.1540-8159.1993.tb.01018.x

16. Gardini A, Benedini G. Blind extrathoracic subclavian venipuncture for pacemaker implant: a 3-year experience in 250 patients. Pacing Clin Electrophysiol. 1998;21(11 Pt 2):2304-8

17. Imnadze G, Awad K, Wolff E, Amberger J, Franz N, Thale $J$, et al. A novel method of axillary venipuncture using the cephalic vein as a sole anatomic landmark. The Can J Cardiol. 2015;31(8):1067-9. https://doi.org/10.1016/j. cjca.2015.02.021

18. Pittiruti M, Biasucci DG, La Greca A, Pizza A, Scoppettuolo G. How to make the axillary vein larger? Effect of 90 degrees abduction of the arm to facilitate ultrasound-guided axillary vein puncture. J Crit Care. 2016;33:38-41. https://doi. org/10.1016/j.jcrc.2015.12.018

19. Squara F, Tomi J, Scarlatti D, Theodore G, Moceri P, Ferrari E. Self-taught axillary vein access without venography for pacemaker implantation: prospective randomized comparison with the cephalic vein access. Europace. 2017;19(12):2001-6. https://doi.org/10.1093/ europace\%2Feuw363

20. Sharma G, Senguttuvan NB, Thachil A, Leong D, Naik N, Yadav $R$, et al. A comparison of lead placement through the subclavian vein technique with fluoroscopy-guided axillary vein technique for permanent pacemaker insertion. Can J Cardiol. 2012;28(5):542-6. https://doi.org/10.1016/j. cjca.2012.02.019

21. Holubec T, Ursprung G, Schonrath F, Caliskan E, Steffel J, Falk $\checkmark$, et al. Does implantation technique influence lead failure? Acta Cardiol. 2015;70(5):581-6. https://doi.org/10.2143/ AC.70.5.3110519

22. Kim KH, Park KM, Nam GB, Kim DK, Oh M, Choi H, et al. Comparison of the axillary venous approach and subclavian venous approach for efficacy of permanent pacemaker implantation. 8-Year follow-up results. Circulation. 2014;78(4):865-71. https://doi.org/10.1253/circj.CJ-13-0884

23. Chan NY, Kwong NP, Cheong AP. Venous access and longterm pacemaker lead failure: comparing contrast-guided axillary vein puncture with subclavian puncture and cephalic cutdown. Europace. 2017;19(7):1193-7. https://doi. org/10.1093/europace/euw147

24. Jacobs DM, Fink AS, Miller RP, Anderson WR, McVenes RD, Lessar JF, et al. Anatomical and morphological evaluation of pacemaker lead compression. Pacing Clin Electrophysiol. 1993;16(3 Pt 1):434-44.

25. Ramza BM, Rosenthal L, Hui R, Nsah E, Savader S, Lawrence $J \mathrm{H}$, et al. Safety and effectiveness of placement of pacemaker 
and defibrillator leads in the axillary vein guided by contrast venography. Am J Cardiol. 1997;80(7):892-6. https://doi. org/10.1016/s0002-9149(97)00542-0

26. Kirkfeldt RE, Johansen JB, Nohr EA, Moller M, Arnsbo P, Nielsen JC. Pneumothorax in cardiac pacing: a populationbased cohort study of 28,860 Danish patients. Europace. 2012;14(8):1132-8. https://doi.org/10.1093/europace/ eus054

27. Saad EBFF, Veronese F, Maldonado P, Camanho LE. Uso do acesso venoso axilar para implante de eletrodos de marcapassos e desfibriladores. Relampa. 2006;19(4):259-99.

28. Orihashi K, Imai K, Sato K, Hamamoto M, Okada K, Sueda T. Extrathoracic subclavian venipuncture under ultrasound guidance. Circ J. 2005;69(9):1111-5. https://doi.org/10.1253/ circj.69.1111

29. Aggarwal RK, Connelly DT, Ray SG, Ball J, Charles RG. Early complications of permanent pacemaker implantation: no difference between dual and single chamber systems. $\mathrm{Br}$ Heart J. 1995;73(6):571-5. https://doi.org/10.1136/ hrt.73.6.571.

30. Chauhan A, Grace AA, Newell SA, Stone DL, Shapiro LM, Schofield PM, et al. Early complications after dual chamber versus single chamber pacemaker implantation. Pacing Clin Electrophysiol. 1994;17(11 Pt 2):2012-5.
31. Marinoni G, Broglia P, Bruno N, Perotti R, Bosatra C, Montemartini C. Percutaneous approach in the use of subclavian vein in pacemaker implantation. Giornale italiano di cardiologia. 1994;24(6):685-9.

32. Eberhardt F, Bode F, Bonnemeier H, Boguschewski F, Schlei $M$, Peters $W$, et al. Long term complications in single and dual chamber pacing are influenced by surgical experience and patient morbidity. Heart. 2005;91(4):500-6. https://doi. org/10.1136/hrt.2003.025411

33. Fiorista F, Lazari M, Marzegalli M, Piane C, Cotti R, Casazza $F$, et al. Use of the subclavian vein for permanent cardiac stimulation. Arch Inst Cardiol Mex. 1986;56(4):309-13.

34. Hess DS, Gertz EW, Morady F, Scheinman M, Sudduth BK. Permanent pacemaker implantation in the cardiac catheterization laboratory: the subclavian vein approach. Cathet Cardiovasc Diagn. 1982;8(5):453-8

35. Kircanski B, Vasic D, Savic D, Stojanov P. Low incidence of complications after cephalic vein cutdown for pacemaker lead implantation in children weighing less than 10 kilograms: A single-center experience with long-term follow-up. Heart Rhythm. 2015;12(8):1820-6. https://doi. org/10.1016/j.hrthm.2015.04.025

36. Parsonnet $\mathrm{V}$, Roelke M. The cephalic vein cutdown versus subclavian puncture for pacemaker/ICD lead implantation. Pacing Clin Electrophysiol. 1999;22(5):695-7. 